\title{
マルチ栽培が梅の生育と収量に与える影響
}

\author{
WuYun $^{1} \cdot$ 千家正照 $^{2} \cdot$ 伊藤健吾 $^{3} \cdot$ 矢野宗治 $^{4}$
}

\section{The Influence of Mulch Culture to the Growth and Yield of Plum}

\author{
Wu Yun ${ }^{1}$, Masateru Senge ${ }^{2}$, Kengo Ito $^{3}$ and Muneharu Yano ${ }^{4}$
}

\begin{abstract}
In this study, we aimed to examine the effects of mulch culture on the quality and production of plum. As a result of two years' experiment that ground surface was covered or not by vinyl black film from July $1^{\text {st }}$ to December 31 th, the following effects of mulching were clarified. 1) The mulching can prevent the soil moisture from extremely decreasing and suppress its fluctuation during the continuous dry weather in summer, and increase soil temperature. 2) The mulching tended to hasten leaves fall in autumn, which suggested that the differentiation and formation of flower buds and commutation of nitrogen from leaves had been promoted. 3) The mulching tended to make the total production of plum increase and the variation of individual fruit weight reduced, which expected to improve those economic value. In addition, it was clarified that both of the average individual fruit weight and the total yield of plum were increased if the soil moisture content was maintained around the field capacity during summer season when evapotranspiration was very high.
\end{abstract}

Keywords: Plum; Mulching culture; Leaf fall; Soil moisture content; Variation of individual fruit weight

\section{1 はじめに}

畑作では古くから増収，高品質化，周年生産，省力化 などを目的としてマルチ栽培が行われ，果樹栽培にも 適用されてきた。とくにウンシュウミカンなどのカン キツ類では適用例が多く,ドリップ灌激を組み合わせ たマルドリ方式により糖度上昇など品質の向上が報告 されている（森永ら，2004; 森永ら，2010）。さらに 近年では, カキ, オウトウ, ナシなどを対象としてマ ルチ栽培が行われ, その効果について多数の試験報告 がみられる，たとえば，オウトウでは裂果の発生が抑 制されること（山本ら，2008）, カキでは果実が肥大し 糖度が向上寸ること（松田ら，2011）, 日本ナシでは収 穫期の前進化（松田ら，2002）などの効果が報告され ている. しかし, 日本の代表的な果樹の一つであるウ メを対象としたマルチ栽培の効果については検討した 事例がない.

ウメは中国四川省湖北省が原産地でバラ科サクラ属 スモモ亜属に分類され学名は prunus mumeである. 日 本では古くから観賞用果樹として愛好されていたが, 江戸時代中期から果実利用目的で栽培されるようにな り（熊谷・鈴木，2011）, 平成 23 年度では, 年間生産

${ }^{1}$ 岐阜大学連合農学研究科学生, Student, The United Graduate School of Agricultural Science, Gifu University, 1-1 Yanagido, Gifu, 501-1193, Japan

2 岐阜大学応用生物科学部教授，Professor，Faculty of Applied Biological Science, Gifu University, 1-1 Yanagido, Gifu, 501-1193, Japan (Corresponding Author) E-mail: senge@gifu-u.ac.jp

3 岐阜大学応用生物科学部准教授, Associate Professor, Faculty of Applied Biological Science, Gifu University, 1-1 Yanagido, Gifu, 501-1193, Japan

4 岐阜大学岐阜フィールド科学教育研究センター，Gifu Field Science Center, Gifu University, 1-1 Yanagido, Gifu, 501-1193, Japan
量は約 106,900t，栽培面積は約 16,600ha で，果樹栽培 面積全体の $8.4 \%$ を占め, 我が国において重要な果樹の 一つである（農林水産省，2011）。

本研究の目的は，マルチ栽培によって，貴重な雨水 資源を効率よく利用し，ウメの生育にとって適切な土 袞水分環境の実現を検証することにある。そこで，蒸 発散が最盛期となる夏季から秋季にかけて地表面をビ ニールで被覆し土壌面蒸発による異常乾燥を抑制する 試験区と，被覆しない試験区を設け，ウメの栽培実験 を行った。その結果から，ビニールマルチによる土壌 水分環境などの変化が秋季の落葉やその後のウメの収 量と品質に与える影響を明らかにし, ウメ栽培へのマ ルチングの効果を検証した.

\section{2 試験方法}

\section{1 試験区の概要}

マルチングによる土壤水分環境の相違がウメの生育・ 収量に与える影響を明らかにするため, 岐阜大学柳戸 農場内のウメの果樹園を対象に 2 つ試験区（以下, 試験区 I ，II と称す）を設けた。試験対象としたウメ の品種はベニサシ(紅映)で, 種子が小さく, 果肉が多 いが, 栽培が困難で収量が少ないという特徵がある(木 野, 2011)。樹齢は 20 年 (盛果期が $10 \sim 20$ 年), 樹高約 $3 \mathrm{~m}$ ，樹幹径約 $30 \mathrm{~cm}$, 樹冠径約 $4 \mathrm{~m}$ である. 各試験区の 大きさは $84 \mathrm{~m}^{2}(=3 \mathrm{~m} \times 24 \mathrm{~m})$ で，それぞれ中央に $6 \mathrm{~m}$ 間隔 で 3 本の梅が栽培されている. 岐阜市の気象条件 (1981 ２010 年）は, 年平均降水量 $1,827.5 \mathrm{~mm}$, 年平均気温 $15.8^{\circ} \mathrm{C}$, 年平均風向, 風速 $2.5 \mathrm{~m} / \mathrm{s}$, 年平均日照時間 2085.1 時間である（気象庁，2013）。 
表 1：調查圃場の土壤の物理性試験

\begin{tabular}{|c|c|c|c|c|c|c|c|c|c|c|}
\hline \multirow{2}{*}{\multicolumn{3}{|c|}{ 項目 $\quad$ 深さ $(\mathrm{cm})$}} & \multicolumn{4}{|c|}{ 試験区 I } & \multicolumn{4}{|c|}{ 試験区 II } \\
\hline & & & $0-10$ & $10-20$ & $20-30$ & $30-40$ & $0-10$ & $10-20$ & $20-30$ & $30-40$ \\
\hline \multirow{4}{*}{\multicolumn{2}{|c|}{$\begin{array}{c}\text { 粒度組成 } \\
\left(\mathrm{kgkg}^{-1}\right)\end{array}$}} & 碩 & 0.06 & 0.08 & 0.07 & 0.07 & 0.05 & 0.05 & 0.08 & 0.04 \\
\hline & & 砂 & 0.47 & 0.51 & 0.50 & 0.49 & 0.49 & 0.54 & 0.48 & 0.51 \\
\hline & & シルト & 0.18 & 0.16 & 0.16 & 0.17 & 0.17 & 0.12 & 0.16 & 0.17 \\
\hline & & 粘土 & 0.29 & 0.25 & 0.27 & 0.27 & 0.29 & 0.29 & 0.28 & 0.28 \\
\hline \multicolumn{3}{|c|}{ 土性 $^{* *}$} & $\mathrm{LiC}$ & $\mathrm{LiC}$ & $\mathrm{LiC}$ & $\mathrm{LiC}$ & $\mathrm{LiC}$ & $\mathrm{LiC}$ & $\mathrm{LiC}$ & $\mathrm{LiC}$ \\
\hline \multicolumn{3}{|c|}{ 土粒子密度 $\left(\mathrm{gcm}^{-3}\right)$} & 2.32 & 2.45 & 2.55 & 2.58 & 2.57 & 2.66 & 2.68 & 2.72 \\
\hline \multicolumn{3}{|c|}{ 乾燥密度 $\left(\mathrm{gcm}^{-3}\right)$} & 1.21 & 1.45 & 1.58 & 1.57 & 1.44 & 1.52 & 1.61 & 1.71 \\
\hline \multicolumn{3}{|c|}{ 固相率 $\left(\mathrm{m}^{3} \mathrm{~m}^{-3}\right)$} & 0.52 & 0.59 & 0.62 & 0.61 & 0.56 & 0.57 & 0.60 & 0.63 \\
\hline \multicolumn{3}{|c|}{ 透水係数 $(\mathrm{cm} / \mathrm{s})$} & $3.3 \times 10^{-2}$ & $1.8 \times 10^{-2}$ & $3.1 \times 10^{-4}$ & $3.5 \times 10^{-4}$ & $8.5 \times 10^{-3}$ & $5.8 \times 10^{-3}$ & $8.3 \times 10^{-4}$ & $8.6 \times 10^{-4}$ \\
\hline \multirow{3}{*}{$\begin{array}{l}\text { 土壤水 } \\
\text { 分恒数 } \\
\left(\mathrm{m}^{3} \mathrm{~m}^{-3}\right)\end{array}$} & \multicolumn{2}{|c|}{24 時間容水量 } & 0.403 & 0.369 & 0.354 & 0.313 & 0.389 & 0.358 & 0.352 & 0.323 \\
\hline & \multicolumn{2}{|c|}{ 圑場容水量 } & 0.382 & 0.334 & 0.323 & 0.305 & 0.367 & 0.326 & 0.319 & 0.311 \\
\hline & \multicolumn{2}{|c|}{ 成長阻害水分点 } & 0.334 & 0.283 & 0.274 & 0.257 & 0.318 & 0.272 & 0.271 & 0.265 \\
\hline \multicolumn{3}{|c|}{$\begin{array}{c}\text { 容易有効水分量 }(\mathrm{mm}) \\
\end{array}$} & 6.9 & 8.6 & 8.0 & 5.6 & 7.1 & 8.6 & 8.1 & 5.8 \\
\hline \multicolumn{3}{|c|}{ 全容易有効水分量 $(\mathrm{mm})$} & \multicolumn{4}{|c|}{29.1} & \multicolumn{4}{|c|}{29.6} \\
\hline
\end{tabular}

\begin{tabular}{|c|c|c|c|c|c|c|c|c|c|c|c|c|}
\hline \multirow{2}{*}{$\begin{array}{c}\text { 項目 } \\
\text { 栄養成長 }\end{array}$} & \multirow{2}{*}{\multicolumn{2}{|c|}{$\begin{array}{l}\text { 7月 } \\
\end{array}$}} & \multirow{2}{*}{$\begin{array}{l}9 \text { 月 } \\
\stackrel{\text { 展葉 }}{\longrightarrow}\end{array}$} & 10 月 & 11 月 & 12 月 & \multirow[t]{2}{*}{ 1月 } & \multirow{2}{*}{\begin{tabular}{|c|}
2 月 \\
発芽 \\
\end{tabular}} & 3 月 & 4月 & 5月 & 6 月 \\
\hline & & & & \multicolumn{3}{|c|}{ 落葉 } & & & & & \multicolumn{2}{|c|}{ 新梢 } \\
\hline 生殖成長 & \multicolumn{2}{|c|}{ 花芽分化 } & 花芽完成 & & & \multicolumn{2}{|c|}{ 胚珠等の形成 } & \multicolumn{5}{|c|}{ 生理的な落果 } \\
\hline 栽培管理 & \multicolumn{6}{|c|}{ マルチ敷設 } & 剪定 & 施肥 & & & & $\stackrel{\text { 収穫 }}{\longrightarrow}$ \\
\hline \multirow{2}{*}{ 観測項目 } & & & 葉数調査 & & 葉数 0 & & & \multirow{2}{*}{\multicolumn{2}{|c|}{ 開花数の測定 }} & \multirow{2}{*}{\multicolumn{2}{|c|}{ 結実数の測定 }} & $\begin{array}{l}\text { 収穫 } \\
\text { 調査 }\end{array}$ \\
\hline & & & 土鎄水分, & 地温の & & & & & & & & \\
\hline
\end{tabular}

図1：試験区の栽培管理

\section{2 土壤条件}

各試験区の表層から深さ $5 \mathrm{~cm}, 15 \mathrm{~cm}, 25 \mathrm{~cm}, 35 \mathrm{~cm}$ におい て撹乱土および不擋乱土 (100ccサンプラー)を採取し, 土壌の物理性を分析した（表 1 ）。いずれの層も磎率は $10 \%$ 以下と小さく, また, 砂 $(0.02 \sim 0.2 \mathrm{~mm})$ 成分と, 粘 土 $(0.002 \mathrm{~mm}$ 未満 $)$ 及びシルト $(0.02 \sim 0.002 \mathrm{~mm})$ を合わ せた成分の割合が，それぞれ $50 \%$ 前後であり，粒度分 布の広がりを表す均等数Ucの值が全層において, Uc $>10$ を満たし，粒度分布の良い土壤であった。国際土 壌学会法による土性区分は，両試験区とも深さ $0 \mathrm{~cm} \sim$ $40 \mathrm{~cm}$ が全て軽植土に分類される。ささらに，いずれの土 層においても固相率が50〜 60\%を占めており，ウメの 生育に適していると判断される(相馬ら，1991）。透水 係数は上層で大きく $\left(10^{-2} \mathrm{~cm} / \mathrm{s}\right.$ 前後 $)$, 下層ほど小さく なる傾向を示し, 固相率との間に強い相関が見られた. また，これらの数值から，試験区の表層土袞は透水性 が大きく，降雨が浸透しやすい特徵を有していること がわかる。保水性試験 ( $\mathrm{pF}$ 試験) の結果から, 各深さの 土層の容易有効水分量 $(24$ 時間容水量～成長阻害水分 点: pF3.0) から深さ $40 \mathrm{~cm}$ の全容易有効水分量を求めた ところ, 試験区 I で $29.1 \mathrm{~mm}$, 試験区 II で29.6mm とな り，両試験区の土壤の保水性はほぼ等しい.

\section{3 観測項目と方法}

\subsection{1 栽培管理と試験区の設定}

試験区における 1 年間の栽培管理を図 1 に示した.マル チによる土壌面蒸発抑制及び土壌水分保持効果を把握 するため，土褰面を黒色ビニールで被覆した「マルチ 区」（写真 1) と，その対照区としてビニール被覆しな い「非マルチ区」(写真 2)を設けた。2010 年は試験区 II をマルチ区，試験区 I を非マルチ区とした。 2011 年 は果樹の個体差の影響を除去するため, 試験区 I をマ ルチ区，試験区 II を非マルチ区として実験を行った. マルチ敷設期間は，両年とも蒸発散が最盛期となる 7 月 1 日から落葉が終了する 12 月 31 日までとした.

樹勢を維持し樹内栄養分の分散を防ぐこと, また樹 冠内部の日照条件を改善し光合成の促進を図ることを 目的として，1 月上旬に徒長枝と結果枝を剪定した。 剪定枝の総重量を測定し, 可能な限り両試験区の剪定 量が等しくなるように注意を払った (表 2 参照)。さら に，剪定後，休眠期の 2 月上旬に鶏粪を試験樹の幹の 周りに $10 \mathrm{~kg}$ ずつ施肥した.

\subsection{2 土壤水分・地温・降雨量の測定}

マルチ区と非マルチ区の土壌水分環境の違いを把握す るために, TDR 水分計（EC-20, Decagon Devices 社製） を設置した。すなわち，両試験区の地表面を基準面と して深さ $10 \mathrm{~cm}$ ごとに 5 層に分割し, 各層の土壌水分 


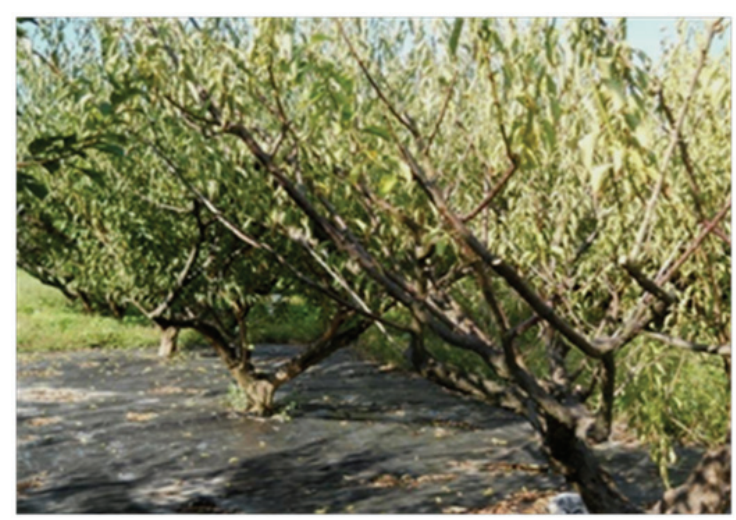

写真 1：マルチ区

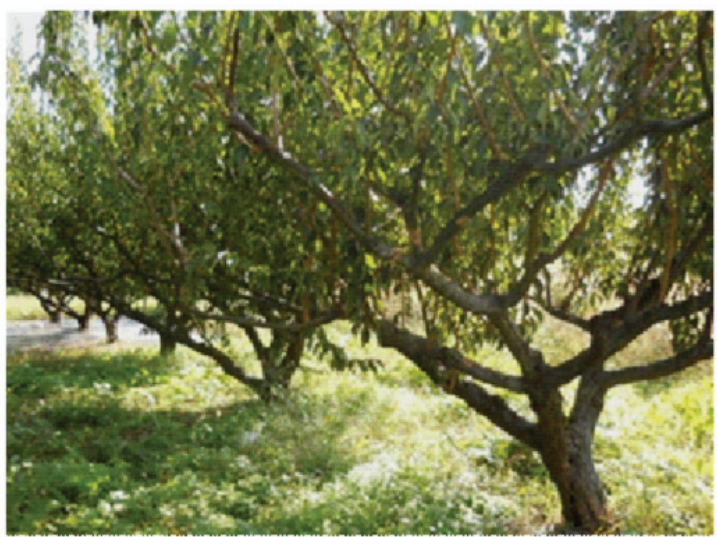

写真 2：非マルチ区

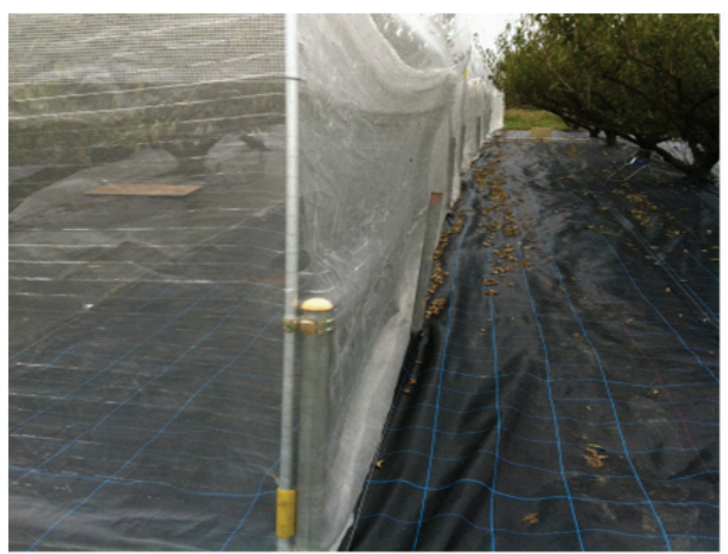

写真 3：落葉調査の状況

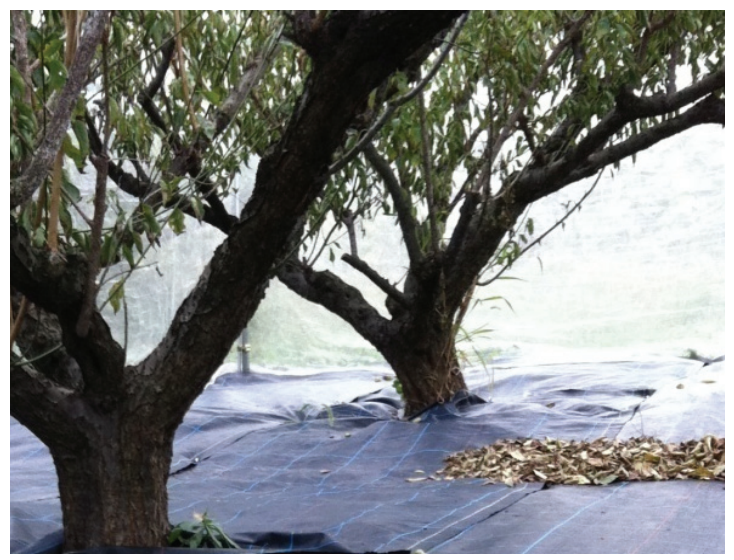

写真 4：落葉調査の状況
量の平均值を測定するために長さ $20 \mathrm{~cm}$ のセンサーを 地表面に対して $30^{\circ}$ の角度で挿入し，10 分間間隔で体 積含水率を自記記録した. 2011 年には TDR 水分計と 同じ深さに温度計 (HOBO U12 Outdoor/Industrial 4ext channe/s, オンセット社) を設置し, 10 分間間隔で地温 を自記記録した。なお, 両試験区の近接した場所に転 倒マス型雨量計 (HOBO H07-002-04, Onset 社) を設置し $0.5 \mathrm{~mm}$ 単位で雨量の自記記録を行った.

\subsection{3 落葉調査}

はじめに，展葉期の9 月に各試験樹の全葉数を測定し た。さらに，落葉期間である 10 月 20 日〜 12 月 15 日 に, 両試験区の周囲をそれぞれ高さ約 $3 \mathrm{~m}$ のネット（目 の大きさ $5 \mathrm{~cm}$ ) で囲い（写真 3 ), 両試験区内の供試樹 からの落葉が周辺に飛散しないようにし，2010 年と 2011 年のそれぞれの落葉期間中に毎日の落葉数を計数 した（写真 4）.

\subsection{4 着花数, 結実数, 糖度及び果実品質調査}

2010 年と 2011 年の 3 6 月に両試験区の 6 本の供試樹 の着花数, 結実数を計数し, 結実率 (=結実数 / 着花 数 $\times 100 ）$ を求めた. 収穫期には収穫個数を計数し電子 天科で総重量を測定した.さらに, 両試験区からサンプ ルとしてそれぞれ 100 個ずつの梅を無作為に抽出し, 糖度計（ATAGO N-1E Brix0～32\%）により糖度を測定 し, 平均值と標準偏差を求めた。 また, 100 個の果実 の個体重を測定し，個体重の分布を調査した。

\section{3 実験結果及び考察}

\section{1 マルチが土潩水分量に与える影響}

一般に, ウメの根群は, 太根, 細根ともほとんどの根

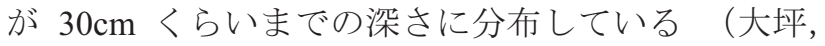
2009）。そこで，ビニールによる被覆期間（7月 1 日〜 12 月 31 日）について, この根群域の土壤水分消費に 影響すると考えられる深さ $50 \mathrm{~cm}$ までの平均土壌水分 量（体積含水率\%) を図 2 , 図 3 に示した。 非マルチ区 は降雨が土壌面から直接浸透するので降雨時には顕著 な土壤水分増加が確認されたが，干天が続くと蒸散に 加えて土畩面蒸発によって土壌水分量が著しく減少す る傾向が見られた。

2010 年の土壌水分量の変化について見ると, 干天が 17 日間継続した 9 月 1 日では, 非マルチ区は $17 \%$ まで 減少し，とくに根群が集中する深さ $20 \mathrm{~cm}$ までの体積 含水率は $10 \%$ まで低下し, 成長阻害水分点を大きく下 回っていた。一方，マルチ区は土壌面をビニールで被 覆していることから直接降雨の侵入は少ないが, 降雨 時には土壌水分の増加が若干確認できた。しかし，干 天時には土㙵面蒸発が制限されることから，非マルチ 区に比べて土䁃水分の減少が著しく抑制され，干天が 長期間継続した 9 月 1 日でも平均含水率は $23 \%$ を維持 していた。 すなわち, マルチ区の土壌水分は非マルチ 区に比べて降雨や土壌面蒸発の影響を受けにくく安定 していた.

一方，2011 年では，マルチ区，非マルチ区ともに蒸 


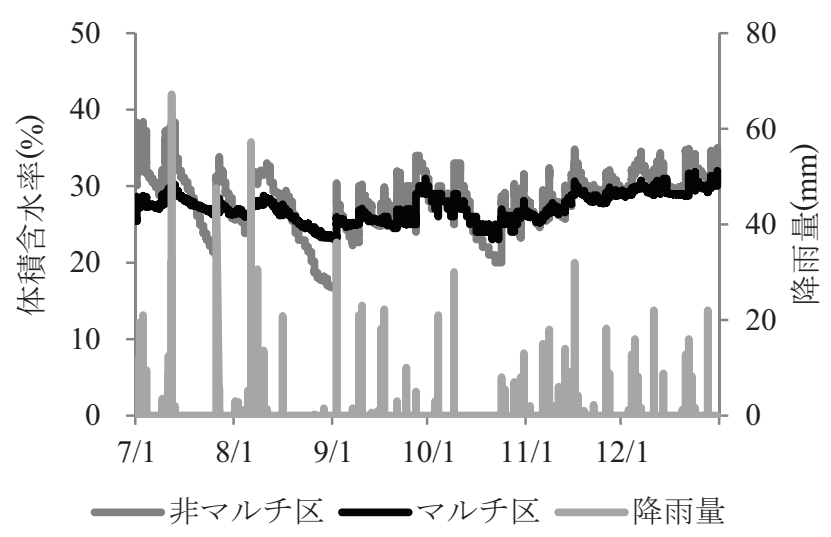

図 2：降雨と土䁃水分の変動 (2010 年)

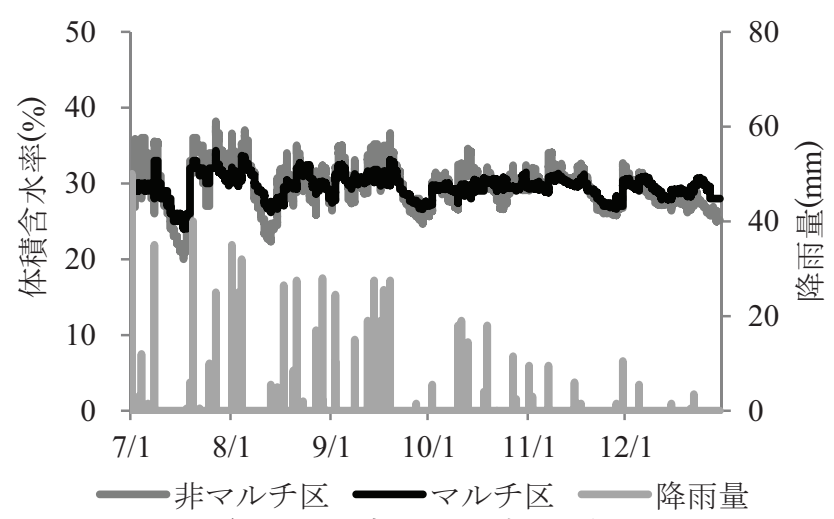

図 3：降雨と土㙋水分の変動（2011 年）

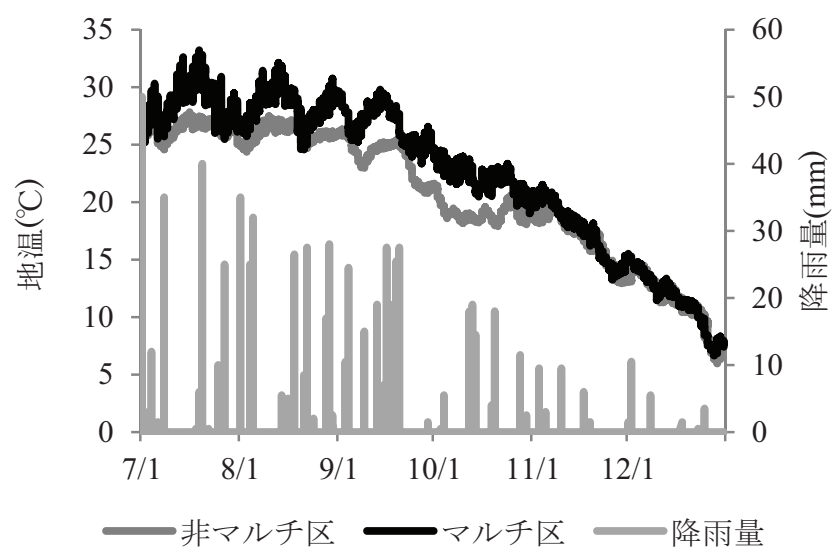

図 4：地温と雨量の関係（2011 年）

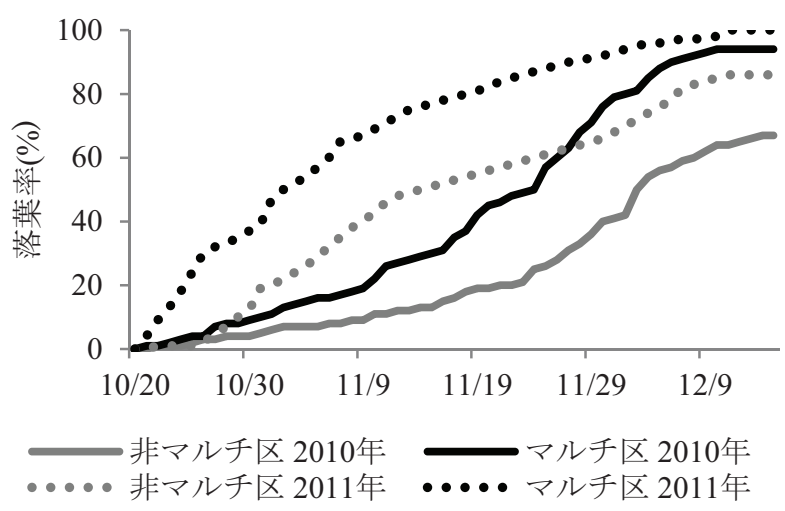

図 5：落葉率（2010,2011 年)
発散が最も盛んなこの時期の土壌水分量は 2010 年と 比べて高く維持されていた。この理由として, 蒸散の 盛んな落葉開始前までの前半（7月 1 日〜9月 30 日）に ついて注目寸ると, 2010 年の降雨量は $529.8 \mathrm{~mm}$ と 2011 年の $541.0 \mathrm{~mm}$ とほぼ同じであったが，2010 年は 7 月 16 日から 7 月 28 日の 13 日間と 8 月 16 日から 9 月 2 日の 16 日間と長期間の連続干天が 2 回あったのに対し, 2011 年は 7 月 8 日から 7 月 18 日の 11 日間の連続干天 が最も長く, この期間を通じて比較的均等に降雨があ ったことが考えられる.

\section{2 マルチが地温に与える影響}

2011 年に測定した深さ $35 \mathrm{~cm}$ までの平均地温の経時変 化を図 4 に示す。マルチ区の 7 月 1 日から 10 月 31 日 までの平均地温は非マルチ区よりマルチ区の方が高く なっていた。 とくに, 干天が続くと両試験区の地温差 が $5^{\circ} \mathrm{C}$ 前後まで拡大しマルチ区では $30^{\circ} \mathrm{C}$ を越えること もあるが，降雨があると地温差が減少する傾向が見ら れる。一方, 気温が低下寸る 11 月 1 日以後は両試験区 の地温差がなくなる.

地温とウメの生育・収量の関係については, 地温が 連続して $36^{\circ} \mathrm{C}$ 以上になる, または短期間でも $40^{\circ} \mathrm{C}$ 上上 になると高温障害により樹勢が低下し収量が減少する ことが報告されている(岡室ら，2010)。本実験ではマ ルチ区においても最高地温は $35^{\circ} \mathrm{C}$ 未満であり, 高温障 害によるウメへの影響は無かったと考えられる。

\section{3 マルチがウメの生育・収量等に与える影響}

一般に, ウメの貯蔵栄養分は果実収穫後の光合成によ って徐々に貯えられ, 落葉直前に最も多くなる。 しか し, 樹体の栄養状態の不良あるいは台風や病害虫の発 生, 旱魅, 低温多雨, 日照不足などによって早期に落 葉すると光合成が不十分になり，樹体はそれまでの蓄 積した養分を消耗し, この結果、花芽の着生の減少, 不完全花の割合が増え結実率が低下し, 収量の減少を 招くことが報告されている（宮原，2009）。また，宮原 ら（1978）は，9 年生剣先を供試して, 花芽発育期の 摘葉処理が翌年の花質, 結実に及ぼす影響を調査した ところ，8 月から 9 月にかけて摘葉処理を行うとウメ の結実安定の基本となる短果枝の結実を低下させ, 収 量への影響が大きいことを明らかにしている。以上の ことから, 落葉期はできるだけ遅らせ全樹が一斉に自 然に落葉することが大切である (小川, 2009). しかし, ウメは浅根性で，養水分を吸収する細根の $90 \%$ が深さ $20 \mathrm{~cm}$ までに分布しており, 収穫後に梅雨明けの旱䰠な どが続くと旱害を受けやすく, 葉の萎调, 収縮, 早期 落葉などの障害が生じ，樹体が衰弱して翌年の開花， 結実に影響するとされている.

そこで，マルチの敷設が落葉に及ぼす影響を検討す るために, 落葉期直前の 9 月に計数した総着葉数と 10 月以降の落葉期に毎日計数した落葉数から落葉率 (= 累加落葉数 / 総着葉数 $\times 100)$ を求め, 図 5 に示した. 2011 年の落葉のピークは 2010 年と比較して約 1 ケ月 程度落葉が早まったこと, また, 両年ともマルチ区 
表 2：2010 年～2011 年の調査結果

\begin{tabular}{|c|c|c|c|c|c|c|c|c|c|c|}
\hline 年 & 試験区 & 処理 & $\begin{array}{l}\text { 剪定量 } \\
\text { ( } \mathrm{kg} / \text { 木) }\end{array}$ & $\begin{array}{l}\text { 着花数 } \\
\text { (個/木) }\end{array}$ & $\begin{array}{l}\text { 着果数 } \\
\text { (個/木) }\end{array}$ & $\begin{array}{c}\text { 結実率 } \\
(\%)\end{array}$ & $\begin{array}{c}\text { 収穫個数 } \\
\text { (個/木) }\end{array}$ & $\begin{array}{c}\text { 個体重 } \\
\text { （g/個） }\end{array}$ & $\begin{array}{l}\text { 生産量 } \\
\text { (kg/木) }\end{array}$ & $\begin{array}{c}\text { 糖度 } \\
(\%)\end{array}$ \\
\hline \multirow{2}{*}{2010 年 } & 試験区 II & 非マルチ & 69.4 & 7,951 & 2,796 & 35.2 & $1,054 \pm 223$ & $18.4 \pm 4.6$ & $19.4 \pm 2.6$ & $7.04 \pm 0.12$ \\
\hline & 試験区 I & マルチ & 64.5 & 9,817 & 4,637 & 47.2 & $1,441 \pm 258$ & $16.1 \pm 2.3$ & $23.2 \pm 3.4$ & $7.03 \pm 0.10$ \\
\hline \multirow{2}{*}{2011 年 } & 試験区 I & 非マルチ & 73.2 & 14,599 & 4,708 & 32.2 & $8,77 \pm 217$ & $26.0 \pm 5.1$ & $22.8 \pm 7.7$ & $6.97 \pm 0.53$ \\
\hline & 試験区 II & マルチ & 71.9 & 16,190 & 5,426 & 33.5 & $1,095 \pm 307$ & $24.4 \pm 3.1$ & $26.7 \pm 7.0$ & $6.99 \pm 0.41$ \\
\hline
\end{tabular}

※ 土は標準偏差

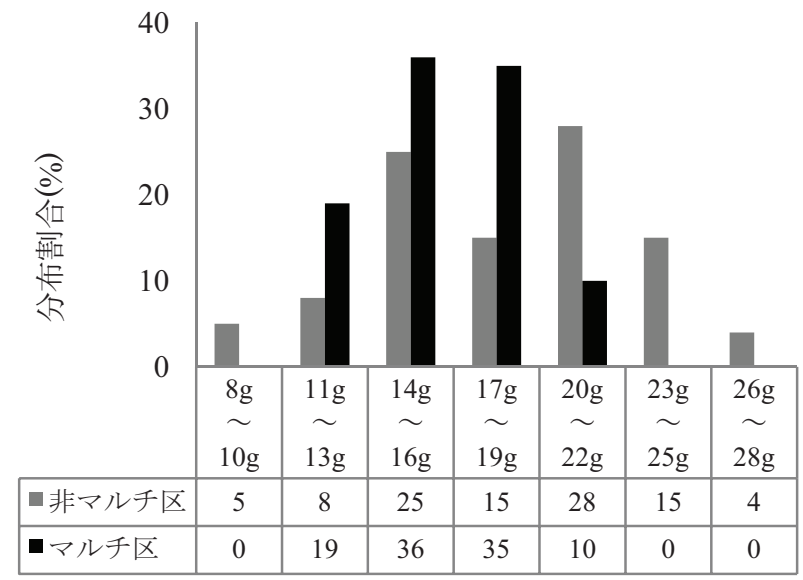

図 6：個体重の分布割合（2010 年）

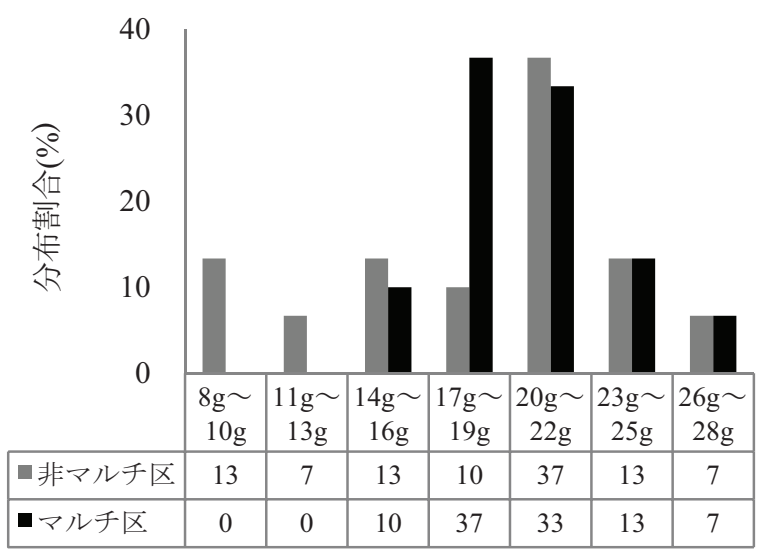

図 7：個体重の分布割合（2011 年）

の方が非マルチ区よりも落葉が早く進む傾向が見られ た. とくに長期間の連続干天があって土壌水分が全般 的に少なかった 2010 年の方は落葉が遅く, 夏季の土㙋 面蒸発によって一時期的に土䁃の異常乾燥が発生した 非マルチ区の方が落葉は遅くなっていた。

表 2 に, ウメの生育指標(着花, 結実, 収穫量等)の 調査結果を示した。マルチ区と非マルチ区を比較する と, 2010 年, 2011 年ともに, 着花数, 着果数, 結実 率，収穫個数，生産量はマルチ区の方が大きく，さら に試験区 I , 試験区 II ともに, 収穫個数, 生産量はマ ルチ区の方が大きくなった。一方，2010 年と 2011 年 を比較すると, マルチ区, 非マルチ区, あるいは試験 区 I , 試験区 II に限らず, 着花数, 着果数, 個体重の
平均值は，2011 年の方が大きくなる傾向にあった。試 験区 I と試験区 II を比較すると，全ての項目について マルチの有無や，2010 年と 2011 年の気象条件の違い による影響を受け，両試験区間に明瞭な差異は見いだ せなかった。

図 6，7 は，ウメの個体重の度数分布を表している. 2010 年, 2011 年ともに, マルチ区はバラツキが小さく 中央值付近でピークを形成する一山型の分布形をして いるが，非マルチ区はバラツキが大きく明瞭な分布形 が見られない。一般に, ベニサシ (紅映)種は, 個体重 $15 \mathrm{~g}$ 以下の果実は商品価值がなく廃棄される。 そこで, 個体重 $15 \mathrm{~g}$ 以上の果実の個数が全収穫個数に占める割 合を調べたところ，2010 年では非マルチ区が $83 \%$ に対 してマルチ区が 91\%, 2011 年では非マルチ区が $80 \%$ に 対してマルチ区が $98 \%$ となった。このように，両年と もマルチ区の方が個体重のバラツキが小さくなり，個 体重 $15 \mathrm{~g}$ 以上の占める割合が大きくなる明瞭な傾向が 見られた。

カンキツ類ではマルチ栽培を用いて糖度を高める試 みが行われている（森永ら，2004）が，保存食に利用 される場合が多いウメは糖度の上昇は腐敗を招くため にその抑制が必要となる（駒野・小林，2007）。本研究 結果では，マルチ区および非マルチ区で糖度に有意差 は見られず，マルチ栽培によりウメの糖度が増加する という問題は見られなかった。

\section{4 考察}

以上の結果を総括すると, 試験区 I と試験区 II の供試 樹の個体差よりも，マルチの有無や年度ごとの気象条 件の差異の方が，表 2 に示した生育指標に与える影響 が大きいことを示唆している。とくに，蒸発散や光合 成の盛んな夏季 (7月～9 月) の土壌水分条件に注目す ると（図 2，3 参照），2010 年は成長阻害水分点の前 後で推移し乾燥条件であったのに対し，2010 年は圃場 容水量前後の比較的好条件の土壌水分状態であった。 その結果， 2011 年の着花数や着果数が 2010 年と比較 して増加しているとともに，個体重の平均值が著しく 増加している。一方，マルチ区は非マルチ区と比較す ると, 収穫個数と生産量が増加するとともに，個体重 のバラツキが小さくなり商品価值のない個体重 $15 \mathrm{~g}$ 以 下の果実の発生確率が減少する傾向が顕著にみられた. これは, マルチングが夏季の土壌面蒸発と土㖶水分の 異常乾燥を抑制したことによって，非マルチ区と比較 
して土鎄水分が安定していたことなどに起因するもの と考えられる.

落葉時期は, 非マルチ区よりマルチ区の方が，また 2010 年より 2011 年の方が明らかに早まる傾向が見ら れたが，これは水分ストレスなどの原因による異常落 葉ではないと推察される。すなわち, 蒸発散が盛んな 時期に好適でから安定した土壤水分環境が得られると, 光合成が十分に行われ多くの炭水化物が蓄積されるの で，花芽の分化・形成が促される（大坪，2009）。そ の結果, 葉からの花芽への窒素の転流が早期に終了し, 落葉が早まったものと推察される.

\section{4 まとめ}

ウメの生育にとって適切な土壤水分管理について検討 することを目的として, 蒸発散が最盛期となる夏季か ら落葉が終了するまでの期間に地表面をビニールで被 覆し, 土袞面蒸発による異常乾燥を抑制する試験区と, 被覆しない試験区を設定し, ビニールマルチによる土 袞水分環境などの変化が秋季の落葉やその後のウメの 収量と品質に与える影響を明らかにした。 その結果, 以下のようなことが明らかになった。

(1) マルチ区は土畩面蒸発が少ないので, 蒸発散が最 盛期となる夏季に干天が継続しても, 非マルチ区と比 較して土壤水分の減少が抑制され, 安定した土袞水分 環境が得られた. その一方で, マルチ区は非マルチ区よ り地温の上昇が確認された。

(2) 蒸発散が最盛期となる夏季に土壌水分が戋場容水 量付近で高く維持されると (2011 年), 着花数や着果 数, ならびに平均個体重が大きくなり, 相対的に総収 穫量も増大した。

(3)マルチ区は非マルチ区と比較して, 収穫個数と生産 量が増加するとともに, 個体重のバラツキが小さく商 品価值のない個体重 $15 \mathrm{~g}$ 以下の果実の発生率が減少す る傾向がみられた。

(4)蒸発散が盛んな夏季において, 土壌水分が高く安定 する方が, 落葉が早く終了する傾向があった。これは, 花芽の分化・形成とそれに伴う葉からの窒素転流が早 く終了したことによるものと推察され, 翌年の生産量 も増大寸る傾向が見られた。

\section{引用文献}

[1] 木野秀樹 (2011）：果実日本 66(10), 日本園芸農業協同 組合連合会, pp.21-26.

[2] 気象庁 (2013)：岐阜地方気象台 http://www.jma-net.go.jp/giful, (参照 2013-03-01).

[3] 熊谷克巳・鈴木鉄夫(2011): 新版図集果樹栽培の基礎知 識, 農文協, p.186.

［4] 駒野小百合・小林恭一（2007）：屈折糖度計を用いた福 井ウメの干し上がり具合の判定法, 福井県農業試験場 研究報告, 44, pp.31-33.

[5] 松田大 ・羽生剛・ - 小西剛・ 野中勝利・楠見浩二 - 黒沢 俊 北島 宣(2011): カキ‘太秋'のマルチ灌溉処理が収權果実 の品質に及ぼす影響, 京都大学農学研究科附属農場, 2011.3.18 発表資料.

[6] 松田賢一・藤田良和・津川久孝・野畠重典・中野眞一 小浦場卓(2002)：日本ナシ“幸水’の透湿性白色フィルム マルチによる熟期促進, 石川県農業総合研究センター 研究報告, 24, pp.1-10.

[7] 宮原継男(2009)：ウメ樹の生育特性.農業技術体系,果樹 編, 第 8 巻, ウメ, 農文協, p. 63.

[8] 宮原継男(1978): 結実を左右寸る条件.生育過程と技術, 果樹編, 第 8 巻, ウメ, 農文協, p. 62 .

[9] 森永邦久 - 吉川弘恭 - 草場新之助 - 島崎昌彦 $\cdot$ 中尾誠 司・星 电宏・谷川美典(2004) : 露地栽培ウンシュウミ カンにおける周年マルチ点滴かん水同時施肥法の開発, 園学研, 3(1), pp.45-49.

[10] 森永邦久 - 吉川弘恭 - 中尾誠司 - 関野幸二 ・ 村松 昇・長谷川美典(2004)：露地栽培ウンシュウミカンに おける周年マルチ点滴かん水同時施肥法の効果, 園芸 学研究, 3(1), pp.33-37.

[11] 森永邦久 - 吉川弘恭 - 草場新之助 - 島崎昌彦 - 中尾誠 司・星 电宏・谷川美典(2010) : カンキツのマルチ・点 滴かん水同時施肥システムの開発と普及,園学研, 9(2), pp.129-135.

[12] 農林水産省(2011)：分野別分類/作付面積 - 生産量, 被 害，家畜の頭数など/ 作物統計/作沉調査（果樹),

http://www.maff.go.jp/j/tokei/kouhyou/sakumotu/sakkyou_ka zyu/index.html, (参照 2013-03-01).

[13] 小川正毅(2009): 落葉の早晚とその影響,生育過程と技術, 果樹編, 第 8 巻, ウメ, 農文協, p.91.

[14] 岡室美絵子・根来圭一・大江孝明(2010) : 高地温がウメ 樹体に及ぼす影響, 和歌山県農林水産技術センター研 究報告, $11, p p .59-66$.

[15] 大坪孝之 (2009): 各部の形態と生理, 果樹編, 第 8 巻, ウ 丈, 農文協, pp .13-28.

[16] 相馬魁之一前田 隆・高氏 昇・虬川雄介・石田 勲(1991)： 北大農場果樹園の土壌物理環境, 北海道大学農学部農 場研究報告, 27, pp.85-98.

[17] 山本隆儀 - 奥谷紘平 - 田中宏幸 - 川上晃 - 金本明洋 (2008) : 根圈へのマルチ処理が甘果オウトウの裂果, 樹 体水分状態, 果実肥大および品質に及ぼす影響, 園学 研, 7(3), pp.351-358.

この論文の公開の質疑または討議は2014年6月30日 まで受付けます. 